\title{
Laboratory Study of Steel Slag Used in Stabilizing Expansive Soil
}

\author{
Magdi Mohamed Eltayeb Zumrawi ${ }^{1} \bowtie$ \\ Alaa Abdel-Aziz Ali Babikir² (D) \\ 'University of Khartoum, Faculty of Engineering, Department of Civil Engineering Sudan \\ ${ }^{2}$ M.Sc. Student, Civil Engineering Department, University of Khartoum
}

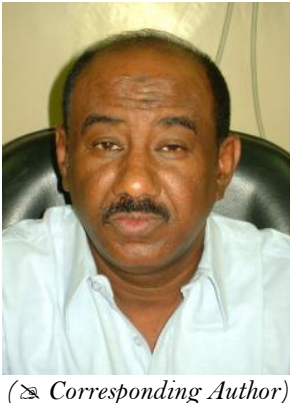

\begin{abstract}
This paper presents an experimental study in stabilization of expansive soil using Steel Slag (SS). Experimental program was conducted to evaluate the influence of Steel Slag on improving the engineering properties of expansive clay. A series of tests to measure consistency limits, free swell index, compaction parameters and unconfined compressive strength of natural and stabilized soils. The effectiveness of adding $0,5,10,15,20$, and 30 percentages of SS to the soil was studied. Comparing the results obtained for the natural and stabilized soils revealed that SS has significant effect on strength parameters and considerable improvement in plasticity and swelling properties. Addition of SS to the soil increased the dry density and decreased the optimum moisture content as well as increased the unconfined compressive strength. It is concluded that the use of steel slag to enhance properties of expansive soil is successful and beneficial.
\end{abstract}

Keywords: Expansive soil, Improving, Steel slag, Strength, Swelling.

Citation | Magdi Mohamed Eltayeb Zumrawi; Alaa Abdel-Aziz Ali Babikir (2017). Laboratory Study of Steel Slag Used in Stabilizing Expansive Soil. Asian Engineering Review, 4(1): 1-6. History:

Received: 25 February 2017

Revised: 7 June 2017

Accepted: 15 June 2017

Published: 20 June 2017

Licensed: This work is licensed under a Creative Commons

Attribution 3.0 License (c))

Publisher: Asian Online Journal Publishing Group
Contribution/Acknowledgement: Both authors contributed to the conception and design of the study.

Funding: This study received no specific financial support

Competing Interests: The authors declare that they have no conflict of interests.

Transparency: The authors confirm that the manuscript is an honest, accurate, and transparent account of the study was reported; that no vital features of the study have been omitted; and that any discrepancies from the study as planned have been explained.

Ethical: This study follows all ethical practices during writing.

\section{Contents}

1. Introduction

2. Literature Review

3. Materials and Methods

4. Results and Discus

5. Conclusions

References 


\section{Introduction}

Expansive soil exhibits significant volume change due to change in moisture content. The clay in this soil is rich of montmorillonite minerals which has great ability to absorb water. The swell-shrinkage behavior of this soil causes damages to infrastructures such as light buildings and road pavements constructed on it. Many stabilization techniques are widely used for improving expansive soil properties.

Chemical additives such as lime, cement, fly ash, inorganic salts and other chemical compounds are commonly used for soil stabilization. In Sudan, cement stabilization is not preferred, because of the increasing cost of Portland cement and environmental hazard due to its application. Hydrated lime is not available and even not suitable for soils containing sulphates, Yadu and Tripathi [1]. With this regard, the demand of finding other alternative materials is necessary. This study focused on the use of industrial waste materials like steel slag to stabilize expansive soil.

Steel slag is a waste produced during manufacturing of iron and steel. Due to rapid growth in steel and iron manufacturing throughout the world, huge amount of waste materials are generated. In Sudan, many factories produce significant quantities of steel slag as the major waste during the manufacture of iron and steel. The estimated daily production of steel slag is 15-20 tons, Zumrawi and Khalill [2]. The disposal of steel slag in landfills may cause environmental hazards. Therefore, utilization of steel slag waste material as an additive to expansive soil can be a proper solution and will help in reducing the environmental pollution. Additionally, this waste material may be introduced in the soil to modify the soil or reduce its swelling potential.

Therefore, it is imperative to carry out a comprehensive study, based on local materials and conditions, to investigate the possibility of utilizing the steel slag in soil stabilization.

\section{Literature Review}

\subsection{Steel Slag Production}

Metal Slag is a waste or by-product material produced during manufacturing process of steel and iron metals. It is divided into two main groups, slag derived from metal production processes consists of ferrous slag and non-ferrous slag; and slag derived from waste heat-treatment and melting. Non-ferrous slag can be further subdivided into Ferronickel slag and copper slag. Ferrous slag can also be further subdivided into Blast Furnace slag and Steel slag. Blast furnace slag may be either granulated slag, air-cooled slag, which has been cooled in the atmosphere, and expanded slag, Akinwumi [3].

Steel slag is produced from various processes that include Open Hearth $(\mathrm{OH})$, Basic Oxygen Furnace $(\mathrm{BOF})$ and Electric Arc Furnace (EAF), Shi [4]. Hot iron (BOF) and/or scrap metal (EAF) are the primary metals to make steel in each process. Lime is injected to act as a fluxing agent.

\subsection{Steel Slag Properties}

Steel slag consists essentially of calcium silicates and ferrites combined with fused oxides of iron, aluminum, manganese, calcium and magnesium that are developed simultaneously with steel. Because it is generated at temperatures of $1200{ }^{\circ} \mathrm{C}$ and greater, steel slag contains no organic matter whatsoever, Akinwumi [3]. Steel slag usually contains four major oxides, namely lime; magnesia; silica and alumina. Minor elements include sulfur; iron; manganese; alkalis and trace amount of several others, Zumrawi and Khalill [2].

The physical properties of steel slag according to National Slag Association (NSA) Environmental Science\& Technology [5] are angular shape, generally well-graded material, has a high degree of internal friction angle and high shear strength. Steel slag has high bulk specific gravity and usually less than $3 \%$ water absorption as well as dry unit weight $1600-1920 \mathrm{~kg} / \mathrm{m}^{3}$, National Slag Association (NSA) Environmental Science\& Technology [5]. According to Proctor, et al. [6] the slag particle size is generally larger than silt or clay, which has an upper size $0.075 \mathrm{~mm}$, and smaller than gravel which has a lower limit of 2 to $5 \mathrm{~mm}$. The mechanical properties of steel slag include good abrasion resistance, good soundness characteristics, and high bearing strength, Zumrawi and Khalill [2]. Due to these mechanical properties steel slag can be used as aggregates in construction projects.

\subsection{Previous Investigations}

Numerous studies have been conducted by various researchers for the use of steel slag to improve the engineering properties of weak soils [1-3];[7-9].

The use of steel slag has been established in a number of applications in the construction industry. Slag can be applied as a material in cement, as road base course material due to large bearing capacity and excellent in wear resistance [7] as aggregate material for the asphalt concrete mixture [8] as fine and coarse aggregates in cement concrete mixture [9] and as improvement weak soil due to high angle of internal friction and high particle density.

Osinubi, et al. [10] studied the effect of using Blast Furnace Slag (BFS) to stabilize a lateritic soil to be used as hydraulic barrier. It was observed that inclusion of BFS increased the CBR value to $10 \%$ of the soil treated with $9 \% \mathrm{BFS}$ and it became suitable for the use as hydraulic barrier.

Oormila and Preethi [11] examined the properties of black cotton soil stabilized using fly ash (FA) and Ground Granulated Blast Furnace Slag (GGBFS).Different percentages of FA and GGBFS were added. They foundthat the stabilizers have significantly improved the index properties of the soil and to achieve the maximum CBR value, the soil was blended with $20 \%$ GGBFS.

Golakiya and Savani [12] investigated the effect of Electric Arc Furnace Dust (EAFD) and Dolime fine addition on black cotton soil to improve geotechnical properties. Electric arc furnace dust generated during steel production and considered as hazardous waste. Dolomite stone is a type of lime stone and additive for slag formation. During the crushing process of Dolomite stone, fine particle is generated known as Dolime fine and regarded as industrial waste. They found that addition of 30\% EAF dust and 12\% Dolime to the black cotton soil had shown a good result. 
Akinwumi [13] who studied soil improvement using electric arc furnace (EAF) steel slag. Various percentages of pulverized steel slag were applied to the soil. It was observed that pulverized steel slag improved the plasticity, uncured strength and drainage characteristics of the soil at the optimum percent of slag $6 \%$.

Biradar, et al. [14] investigated the effect of using Fly ash and Steel slag to stabilize clay soils. Fly ash and Steel slag were mixed at different percentages $0 \%, 10 \%, 20 \%, 30 \%, 40 \%$ and $50 \%$ by weight of the soil to obtain the optimum percentage of admixture required. The study results showed that addition of steel slag and fly ash decreased the consistency limits and increased the CBR value of the soil.

\section{Materials and Methods}

To achieve the current study objective, laboratory testing program was undertaken. Laboratory experiments were conducted on expansive soil to investigate the influence of adding steel slag on its engineering properties.

\subsection{Materials Used}

The expansive soil used in this study was obtained from Buri in Khartoum. The soil is dark grey stiff silty clay. The basic engineering properties of the soil were determined and presented in Table 1.

Table-1. Engineering properties of the soil used

\begin{tabular}{|c|c|c|}
\hline \multirow{2}{*}{\multicolumn{2}{|c|}{$\begin{array}{l}\text { Property } \\
\text { Specific gravity }\left(G_{s}\right) \\
\end{array}$}} & \multirow{2}{*}{$\begin{array}{l}\text { Value } \\
2.70\end{array}$} \\
\hline & & \\
\hline Particle size & $\begin{array}{l}\text { Sand, \% } \\
\text { Silt, \% } \\
\text { Clay, \% }\end{array}$ & $\begin{array}{l}1 \\
17 \\
82\end{array}$ \\
\hline Atterberg's limits & $\begin{array}{l}\text { Liquid limit, \% } \\
\text { Plastic limit, \% } \\
\text { Plasticity index, \% }\end{array}$ & $\begin{array}{l}66 \\
30 \\
36\end{array}$ \\
\hline $\begin{array}{l}\text { Compaction } \\
\text { parameters }\end{array}$ & $\begin{array}{l}\text { Max. Dry Density, kN/m } \\
\text { Optimum Water Content, \% }\end{array}$ & $\begin{array}{l}14.0 \\
27.5\end{array}$ \\
\hline \multicolumn{2}{|c|}{ Free swell index, \% } & 144 \\
\hline \multicolumn{2}{|c|}{ Unconfined compressive strength, $\mathrm{kN} / \mathrm{m}^{2}$} & 222 \\
\hline \multicolumn{2}{|c|}{ Soil classification } & $\mathrm{CH}$ \\
\hline
\end{tabular}

For this study, the steel slag was collected from Giad factory in Khartoum. The steel slag was crushed into finer particles and graded to the desired size, then added in varying proportions by weight to the dry soil sample. The finer particle of steel slag was found non-plastic material. The chemical compositions of steel slag are given in Table 2 below.

Table-2. Chemical composition of steel slag,

\begin{tabular}{l|c}
\hline \multicolumn{2}{c}{ Table-2. Chemical composition of steel slag, } \\
\hline Constituent & Value \\
\hline Calcium oxide $(\mathrm{CaO})$ & 25.8 \\
\hline Silicon dioxide $\left(\mathrm{SiO}_{3}\right)$ & 16.4 \\
\hline Iron $\left(\mathrm{FeO}\right.$ or $\left.\mathrm{Fe}_{2} \mathrm{O}_{3}\right)$ & 26.0 \\
\hline Magnesium oxide $(\mathrm{MgO})$ & 10.0 \\
\hline Manganese oxide $(\mathrm{MnO})$ & 11.2 \\
\hline Aluminium oxide $\left(\mathrm{Al}_{2} \mathrm{O}_{3}\right)$ & 2.4 \\
\hline Titanium oxide $\left(\mathrm{TiO}_{2}\right)$ & 0.8 \\
\hline Free lime $($ free $\mathrm{CaO})$ & 2.1 \\
\hline Source: Akinwumi $[13])$ &
\end{tabular}

\subsection{Sampling and Testing}

The soil was initially air dried and pulverized. The soil samples were prepared by sieving through sieve no. 4 ( $(4.75 \mathrm{~mm})$ and then oven dried at $105-110{ }^{\circ} \mathrm{C}$ for 24 hours. The steel slag was subjected to crushing and sieving through sieve no. $4(4.75 \mathrm{~mm})$. The soil mixed with steel slag at six different contents $(0 \%, 5 \%, 10 \%$, $15 \%, 20 \%$ and $30 \%)$. The dry soil mixed with each percent of steel slag then subjected to testing.

Laboratory tests were conducted to determine the properties of the natural and stabilized soils. The tests carried out include consistency limits, compaction proctor, free swell and unconfined. All tests were performed in accordance to BS 1377 [15]. The consistency tests conducted include the liquid limit and plastic limit tests. The soil was mixed with the fine of steel slag at different percentages then water added for mixing. The prepared sample of stabilized soil was then placed in plastic bags to remain for 24 hours. The liquid limit tests were determined by Cassagrande apparatus and the plastic limit tests were performed according to BS 1377 [15]. The free swell was measured for the natural and stabilized soils in a standard graduated glass cylinder. 50 grams of dry soil mixed with each percentage of steel slag were poured into the glass cylinder of $100 \mathrm{ml}$ capacity filled with water. The swollen volume of the stabilized soil was observed after 24 hours. The free swell index is determined as a percentage increase in the volume to the original volume of the stabilized soil.

Compaction test is usually conducted to determine the compaction characteristics. Proctor compaction tests were performed on natural and stabilized soil with steel slag at different percentages. Unconfined compression tests were carried out on compacted soils at maximum dry density and optimum moisture content. The sample prepared and placed in the compression test machine on the lower plate. The machine adjusted carefully and the deformation indicator set to zero. The load applied and the axial strain deformation values were recorded. The test continued until failure or $20 \%$ axial strain reached. The unconfined compressive strength was determined at failure. 


\section{Results and Discussion}

The tests results are presented and discussed in this section. Table 3 presents the summary of the tests performed to evaluate the effect of steel slag on the engineering properties of the soil. The relationships between each of the properties with the steel slag content are graphically drawn as shown in Figures 1 to 5.

Table-3. Summary of tests results for natural and stabilized soils

\begin{tabular}{l|l|l|l|l|l|l}
\hline \multirow{2}{*}{ Property } & \multicolumn{3}{c}{ Steel Slag Content (\%) } & $\mathbf{1 5}$ & $\mathbf{2 0}$ & $\mathbf{3 0}$ \\
\cline { 2 - 7 } & $\mathbf{0}$ & $\mathbf{5}$ & $\mathbf{1 0}$ & $\mathbf{1 5}$ \\
\hline Liquid limit, \% & 66 & 61 & 58 & 54 & 50 & 44 \\
\hline Plastic limit, \% & 30 & 31 & 33 & 35 & 34 & 35 \\
\hline Plasticity index, \% & 36 & 30 & 25 & 19 & 16 & 9 \\
\hline Free swell index, \% & 144 & 135 & 126 & 110 & 95 & 65 \\
\hline Max. dry density, kN/m ${ }^{3}$ & 14.0 & 14.5 & 15.3 & 14.8 & -- & - \\
\hline Optimum moisture content, \% & 27.5 & 23.5 & 22.4 & 20.6 & -- & -- \\
\hline Unconfined comp. strength, $\mathrm{kN} / \mathrm{m}^{2}$ & 222 & 343 & 522 & 403 & -- & -- \\
\hline Source: the present study & & & &
\end{tabular}

\subsection{Consistency Limits}

The variation in liquid limit (LL) and plastic limits (PL) of the expansive soil stabilized with steel slag is shown in Figure 1. From this figure, it can be seen that increase in steel slag percentage decreases liquid limit and increases plastic limit. Addition of $30 \%$ steel slag to the soil is causing about $33 \%$ reduction in the liquid limit value of natural soil. Also from the plastic limit results, it is noticed that as the percent of steel slag increases from 0 to $30 \%$, there is little increase in the plastic limit values for the soil. As a result, plasticity index decreases as steel slag content increase. At 30\% steel slag, the reduction in plasticity index is about $75 \%$.

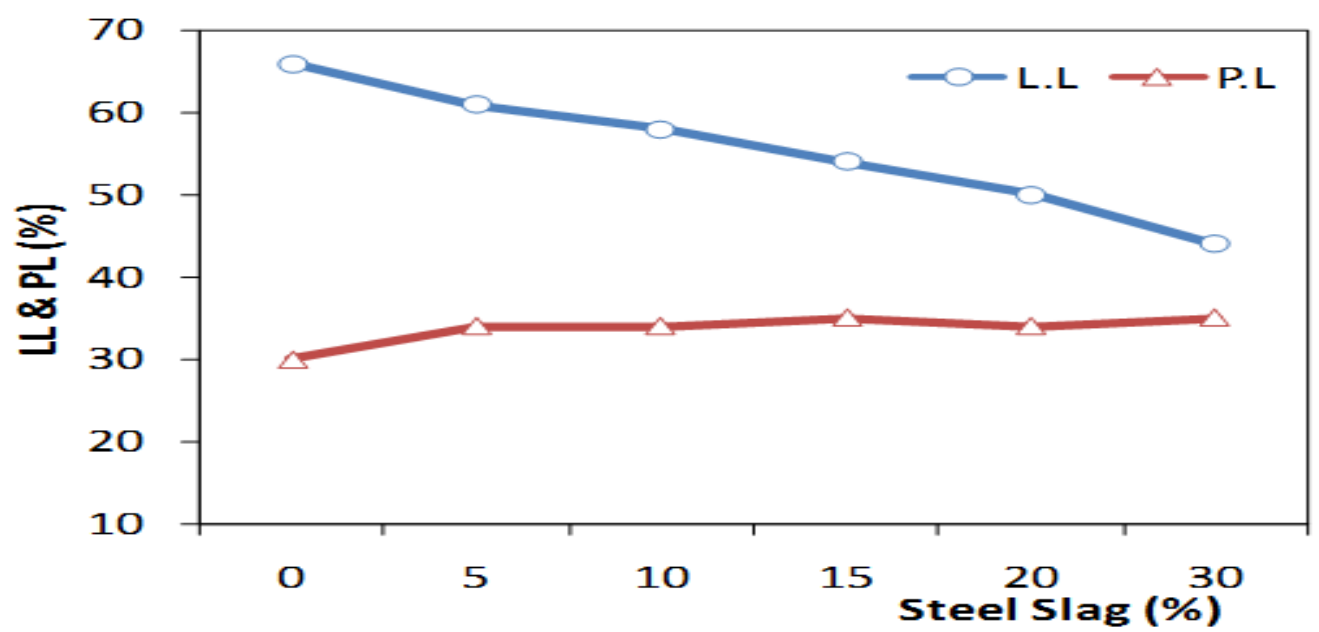

Source: the present study

Figure-1. Influence of steel slag on liquid and plastic limits of the soil.

\subsection{Free Swell Index}

In expansive soil the free swell is the important parameter to understand the severity of problem posed by expansive soil. The variation of Free Swell Index (FSI) with percentages of Steel Slag of the soil is presented in Figure 2. From this figure, it can be observed that as the percentage of Steel Slag increased from o to 30\%, there is a considerable reduction in FSI. The reduction in FSI value is about $55 \%$ with addition of $30 \%$ Steel Slag.

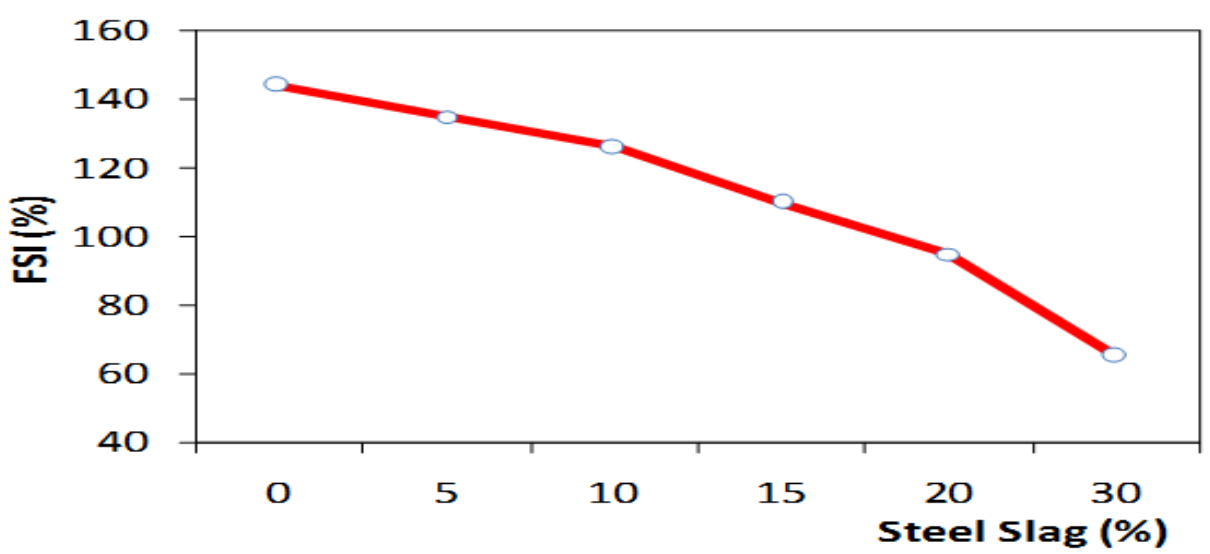

Source: the present study

\subsection{Compaction Characteristics}

The variation of the compaction parameters namely maximum dry density (MDD) and optimum moisture content (OMC) values with different percentages of steel slag added to the expansive soil is presented in Figures 3 and 4. Significant change in MDD and OMC are observed with addition of steel slag to the expansive soil. From Figure 3, it is notice that the MDD increases up to about $10 \%$ of steel slag and thereafter decreases with addition of steel slag to the soil. The reason is due to the high water absorption with addition of steel slag above $10 \%$, this will reduce the soil density. 


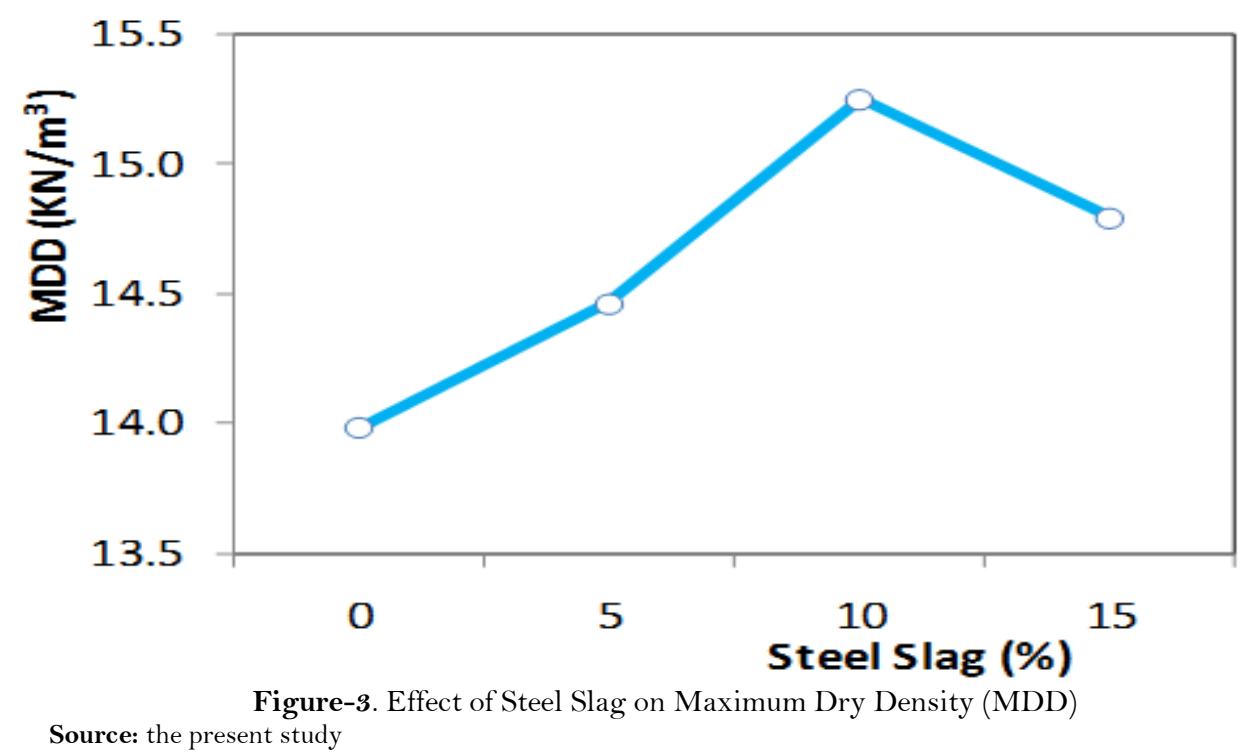

The influence of steel slag with varying percentages on OMC is clearly shown in Figure 4. From this figure, it was seen that there is considerable decrease in OMC with increase the percentage of the steel slag. The reduction in OMC with $15 \%$ steel slag additive is almost $25 \%$ of the initial value of natural soil. The improvement in the compaction parameters with added steel slag may be attributed to the cation exchange between mineral layers.

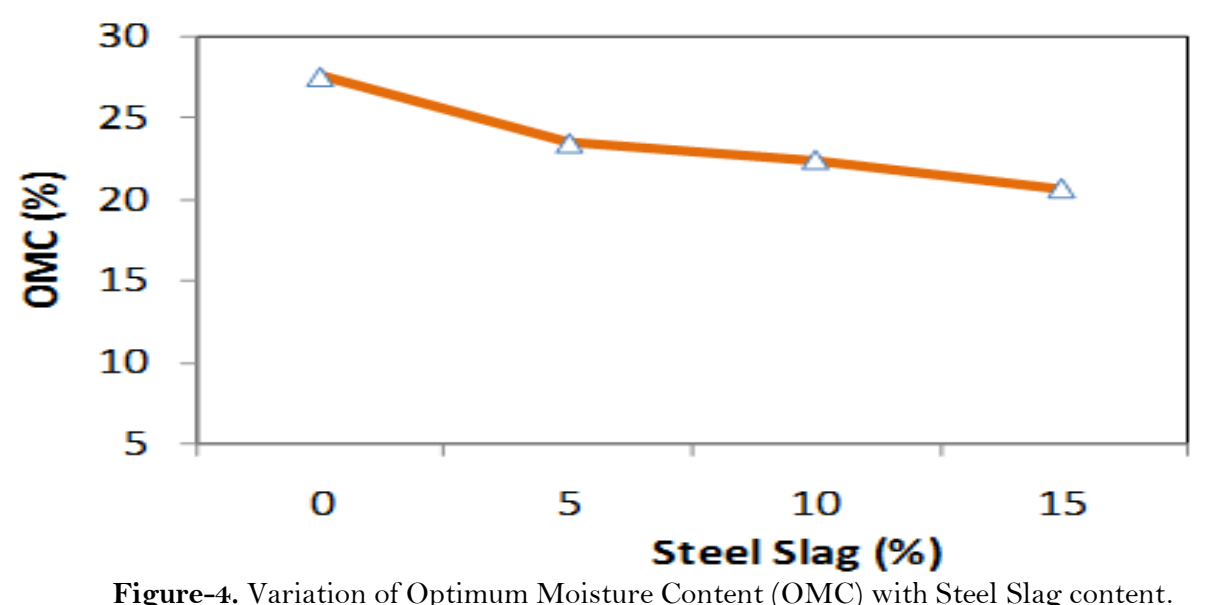
Source: the present study

\subsection{Unconfined Compressive Strength}

The variation of unconfined compressive strength (UCS) of the soil stabilized with Steel Slag is presented in Figure 5. From this figure, it is observed that the UCS values increases with increase in Steel Slag. The UCS values are increased with higher rate up to $10 \%$ steel slag and then decreased with slower rate. The justification of this result may be due to the reduction in density with addition of steel slag beyond $10 \%$. at The UCS value at $10 \%$ steel slag showed almost 1.5 times improvement as compared to untreated soil. Overall from the results, it is understand that the strength of the expansive soil stabilized with steel slag are increasing significantly up to the optimum content of steel slag and then decreases with addition steel slag. Therefore, steel slag can be used to improve the strength characteristics of expansive soil.

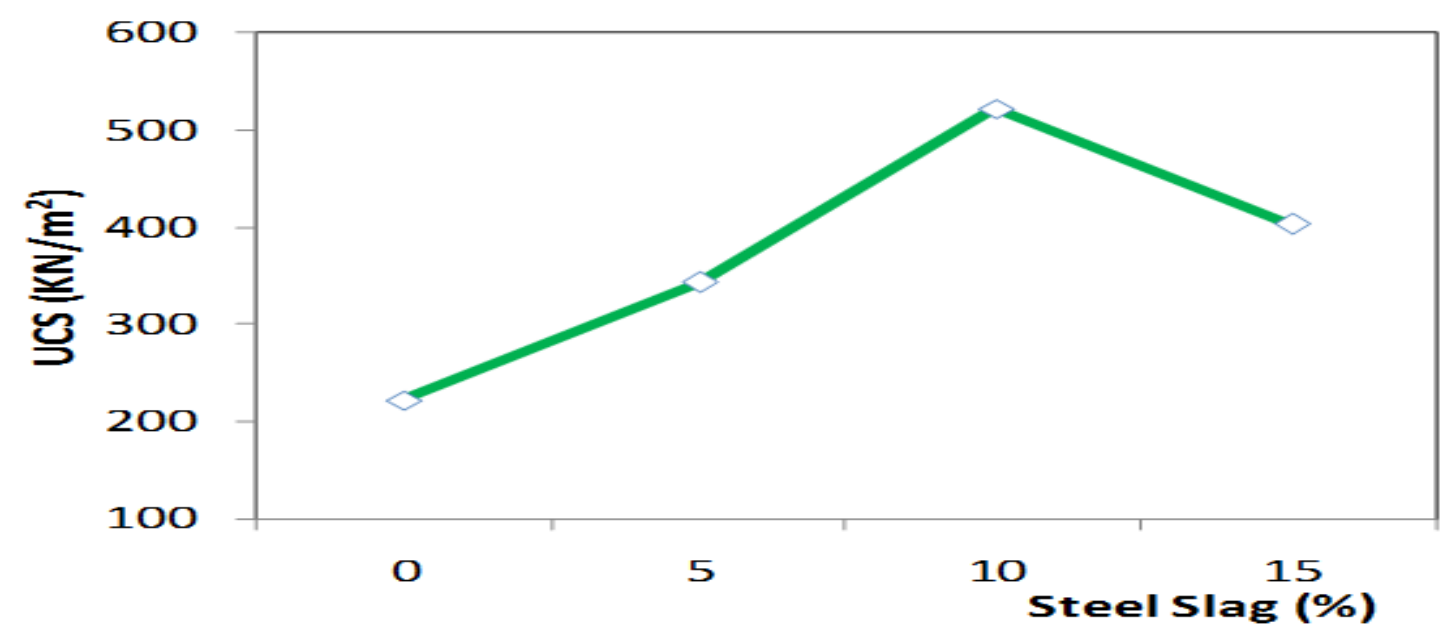

Figure-5. Unconfined compressive strength relationship with steel slag content. Source: the present study

\section{Conclusions}

This study has concentrated on the effect of Steel Slag stabilizer on engineering properties in particular the swelling and strength properties of a highly expansive soil. Based on the study findings, the following 
conclusions are drawn:

- The basic properties of the soil studied were determined, clay content $82 \%$; liquid limit $66 \%$; plasticity index 36\%; free swell index 144\%; unconfined compressive strength $222 \mathrm{kPa}$. The soil is classified as high expansive clay.

- The liquid limit decreases with an increase in Steel Slag content. Addition of Steel Slag to the expansive soil is causing about 33\% reduction in the liquid limit value at 30\% of Steel Slag. For plastic limit, as Steel Slag increases from o to $30 \%$, there is a little increase in the plastic limit values of the stabilized soil. Moreover, plasticity index reduces by $75 \%$ with the addition of $30 \%$ Steel Slag.

- Free swell index is significantly decreased as Steel Slag increases. At 30\% Steel Slag, the free swell index of the soil is decreased and the reduction observed is almost $55 \%$.

- Addition of Steel Slag has major effect on compaction characteristics of the stabilized soil. An increase in Steel Slag content leads to a significant increase in maximum dry density up to $10 \%$ Steel Slag and beyond this percentage. Further addition of Steel Slag is causing gradual decrease in MDD, while a considerable decrease in OMC is observed with increasing percentage of Steel Slag. Therefore, an optimum value of Steel Slag may be taken as $10 \%$ with respect to compaction parameters.

- The strength of expansive soil can be effectively improved by addition of Steel Slag. The Unconfined Compressive Strength (UCS) values increases with increase in Steel Slag. The UCS values of the soil are increased with higher rate up to $10 \%$ Steel Slag and then decrease with slower rate. The UCS value at 10\% Steel Slag showed almost 1.5 times improvement as compared to untreated soils.

\section{References}

[1] L. Yadu and R. K. Tripathi, "Stabilization of soft soil with granulated blast furnace slag and fly Ash," International Journal of Research in Engineering and Technology, vol. 2, pp. 115-119, 2013. View at Google Scholar | View at Publisher

[Q] M. M. E. Zumrawi and F. O. A. Khalill, "Experimental study of steel slag used as aggregate in asphalt mixture," International Journal of Civil, Environmental, Structural, Construction and Architectural Engineering, vol. 9, pp. 683-688, 2015.

[3] I. I. Akinwumi, "Utilization of steel slag for stabilization of a lateritic soil," Ogun State, Thesis, 2012.

[4] C. Shi, "Steel slag-its production, processing, characteristics, and cementitious properties," Journal of Materials in Civil Engineering ASCE, vol. 16, pp. 230-236, 2004. View at Google Scholar |View at Publisher

[5] National Slag Association (NSA) Environmental Science\& Technology, "Steel slag product information." Retrieved from www.nationalslag.org, 2013.

[6] D. M. Proctor, K. A. Fehling, E. C. Shay, J. L. Wittenborn, J. J. Green, C. Avent, R. D. Bigham, M. Connolly, B. Lee, T. O. Shepker, and M. A. Zak, "Physical and chemical characteristics of blast furnace," Basic Oxygen Furnace and Electric Arc Furnace Steel Industry Slags, vol. 34, pp. 1576-1582, 2000. View at Google Scholar

[7] K. Horii, T. Kato, K. Sugahara, N. Tsutsumi, and Y. Kitano, "Overview of iron and steel slag application and development of new utilization technologies," Nippon Steel and Sumitomo Metal Technical Report No. 1092015.

[8] J. Emery, "Steel slag utilization in asphalt mixes. National Slag Association, MF 186-1." Retrieved from www.nationalslagassoc.org, 1984 .

[9] G. Singh, S. Sangwan, and M. Usman, "Experimental study of blast furnace slag concrete," International Journal of Engineering Sciences and Research Technology Experimental, vol. 9655, pp. 475-480, 2015.

[10] K. J. Osinubi, A. O. Eberemu, and A. A. Amadi, "Compacted lateritic soil treated with blast furnace slag as hydraulic barrier s in waste containment systems," International Journal of Risk Assessment and Management, vol. 13, pp. 171-189, 2009. View at Google Scholar | View at Publisher

[11] R. Oormila and T. V. Preethi, "Effect of stabilization using fly ash and GGBS in soil characteristics," International Journal of Engineering Trends and Technology, vol. 11, pp. 284-289, 2014. View at Google Scholar | View at Publisher

[12] H. D. Golakiya and C. D. Savani, "Studies on geotechnical properties of black cotton soil stabilized with furnace dust and dolomitic lime," International Research Journal of Engineering and Technology, vol. 2, pp. 810-823, 2015.

[13] I. Akinwumi, "Soil modification by the application of steel slag," Rperiodica Polytechnica Civil Engineering, vol. 58, pp. 371-377, 2014. View at Google Scholar | View at Publisher

[14] K. B. Biradar, U. Arun, and P. V. V. Satyanarayana, "Influence of steel slag and fly ash on strength properties of clayey soil : A comparative study," International Journal of Engineering Trends and Technology, vol. 14, pp. 61-64, 2014. View at Google Scholar | View at Publisher

[15] British Standard BS 1377, Methods of test for soils for civil engineering purpose. London: British Standard Institution, 1990. 